\title{
Animal Husbandry in the Middle and Lower Polimlje in the Middle Ages
}

\author{
Marijan Premović, PhD \\ University of Montenegro, Faculty of Philosophy, Department of History, Danila Bojovića bb, 81400 Nikšić, Montenegro \\ Email: premovicmarijan@yahoo.com
}

Doi:10.5901/jesr.2014.v4n4p432

\begin{abstract}
In this paper, the terms such as Middle and Lower Polimlje refers to the area of the following medieval parishes: Lim, Ljubovidj (now the territory of municipality of Bijelo Polje, Montenegro), Zvijezd, Crna Stena (the territory of the municipality of Prijepolje, Serbia) and Dabar (includes Priboj, Serbia and Rudo in Bosnia and Herzegovina). The nature in this region, as elsewhere, affected human interests. Meadows and pastures are spread along the rivers and streams, in the villages, in the foothills and mountains. The configuration of the terrain and geographic and climatic characteristics of Polimlje influenced the economic life of the medieval population, which was based on livestock farming as one of the most important industries. As for the original sources for this work, ie. research material on this topic, in addition to relevant published literature, Serbian sources (charters), I used the works of several travelers who visited the area. It should also be noted that the documents of the Ottoman Empire dating from 1475/77 and 1585 were used as well. This Ottoman material has, so far, little been used in researches related to this branch of industry. Professional cattle breeders, known as Vlachs, were organized in kind of pastures and kept a large number of cattle, which they bred through the regime of seasonal movements between winter and summer residences. These livestock groups are listed in defter (cadastral tax census of the Ottoman Empire) from 1475/77 in the districts: Mataruge, Kuknj, Mileševa and Ljubovidj. In the area of Middle Polimlje they had their winter and summer destinations. Livestock breeding in the Middle Ages had multiple significance, animal products provided the necessary food: milk, cheese, sour cream, butter and meat were irreplaceable as food. Livestock had also been used, mainly oxen, in field work. Most of the cultivated animals were sheep, cattle and goats.
\end{abstract}

Keywords: Polimlje, Animal Husbandry, Middle Ages, mountains, defter

\section{Introduction}

Historical sources and bibliography mention five differently sized regions as medieval districts in the area of Middle and Lower Polimlje: Lim, Ljubovidja (the area of the present-day Municipality of Bijelo Polje, Montenegro), Zvijezd, Crna Stena (now Municipality of Prijepolje, Serbia) and Dabar (which included the areas of the present-day Municipalities of Priboj in Serbia and Rudo in Bosnia and Herzegovina). So far, no expert studies (Hadžibergić, 1969; Lutovac, 1977; Katić, 1978) have dealt with the development of animal husbandry in these areas. This paper will attempt to merge the foregoing fractional studies, to expand and synthetize them. At first, the scarcity of preserved original source documents may reasonably seem to pose a research problem. However, a thorough study of the available sources offer sufficient information necessary for the analysis and scientific verification. This study aims to resolve some very important issues that concern the economy of the mentioned area in the Middle Ages which have not been dealt with thus far.

Middle Polimlje stretches longitudinally along the central valley of the Lim river including the surrounding mountains: Bjelasica (2137 m) and Lisa (1509 m) to the left, Ozren (1641 m), Jadovik (1734 m) and Zlatar (1627 m) to the right, as well as the karst plateaus Bihora and Korita. The area of Lower Polimlje is surrounded by Pobijenik (1423 m) and Starovlaške mountains and Sijenička ravine (Dragović, 2004). As everywhere else, human activities in these parts have always been defined by their environment. Therefore, the terrain and geo-climate features of Polimlje determined animal husbandry as one of the key economic activities of the medieval population of this area. Owing to its profitability, animal husbandry developed not only in the mountainous parts but also in the district valleys where farming was a more probable choice.

\section{Mountains and Pastures}

Middle and Lower Polimlje are exceptionally suitable for the development of animal husbandry due to the extensive mountains, pastures, woodland, rivers, streams and fresh water springs. Grazing land stretched by the rivers and streams and also included village meadows and mountain clearings. People of the area practised seasonal transhumance - a semi-nomadic animal husbandry. The animals would spend only a part of the winter and early spring in the district valley, 
and that part of the year corresponded to the sheep lambing period. When the snow started to thaw on the south-facing slopes, the cattle was moved to selinas (T. N. selina is grassland near a village) for about twenty days. From there, they moved on to the lower part of the mountains - the most significant region for animal husbandry as it was the prime source of forage. Towards the end of May, the animals were moved to higher altitudes where they spent several months (Lutovac, 1933). Such transhumance stockbreeding was probably the basis of the regional lifestyle the Middle Ages.

At those times, a configuration would be called "a mountain" only if its peak was very high (over $1000 \mathrm{~m}$ above sea level) and if it contained pastures. In such areas, livestock - sheep and other farm animals - grazed amply from spring to autumn (Blagojević, 1966). In 1662, an Ottoman Turkish travel writer - Evliya Çelebi - wrote that the shepherds of mountain pastures lived in Priboj, Lower Polimlje (Čelebija, 1957).

The charts and other Serbian medieval legal documents, mention numerous mountains, pastures, meadows and katuns of the Middle Polimlje (TN: a katun is a shepherds' summer hut in the mountain and also, as used further in the text - a basic social unit of a stockbreeding community). Some villages in this area even had their own mountains; for instance, we learn from the Ston Chart (issued in 1252) that the village Prošćenje owned a mountain - Konj (it is now the mount of Konjic on the right of the river Tara) (Mošin, Ćirković, \& Sindik, 2011).

Meadows or grassland are bigger or smaller plots of land overgrown in grass. Forage grass - fresh or dried (hey) was the basic livestock food of the time and the Lim valley abounded in it. In Middle Polimlje, the Humska Eparchy had their own grassland and there is record of the church grassland within the boundaries of the village Cerovo. The forage was stored on the meadows and grassland and was the main component of the winter fodder. As it was very difficult to make the supplies for the entire duration of winter, the animals were held on the winter pastures as long as it was possible (Blagojević, 2007). We learn from an Ottoman defter dated 1475/77 that in some areas a tax was paid on forage. This register informs us that the villages owned pastures as they paid tithe on them (Aličić, 1985). Along with the mountains, the major sources of livestock fodder were valley meadows near the villages and pastures on lower altitudes (Blagojević, 2007).

\section{Livestock and Its Products}

Raising farm animals in the Middle Ages was of multiple importance as their products provided day-to-day food such as milk, cheese, kaymak, butter and meat, while wool, fleece and skin provided clothes. Cattle, mainly oxen, were used in land farming. Additionally, as records show, livestock was used as commodity in trading (Kovačević-Kojić, 1987). The main farm animals were sheep, cows and goats. These animals could survive moving over long distances and goat raising was exceptionally profitable owing to their feeding habits as they did not require any food storing for the most part of the year. This area abounded in deciduous forests that provided the main food source for these animals. The number of cattle was closely related to the food supply capacity that directly depended on the size of the available pastoral areas. A variety of pastures throughout Polimlje provided sufficient food for the cattle. These cows and oxen belonged to the indigenous busha breed which is small in size and weight - from 100 to 200 kilos - and capable of moving in steep hilly terrain. However, they were comparably fewer in number than other domestic animals. Additionally, poultry was kept mostly chicken and more rarely - geese and ducks (Katić, 1978). An insight into the approximate livestock population of a household can be gained from a complaint lodged in 1464, by a Stanica Ratkova against three Miokanić brothers Božidar, Vukče and Miluš - from Popovo in Herzegovina for stealing four oxen, ten sheep and ten goats from Stanica's niece Ivana (Mišić, 1996). A Venetian travel writer, Paolo Contarini (1580), wrote that the monks from Mileševa monastery in Prijepolje received a substantial income from raising livestock (Hrabak, 1969).

As a distinctly stockbreeding area, this region needed huge amounts of salt for both people and livestock as salt increases appetite which in turn boosts growth and milk production in livestock. Therefore, stock breeders from Polimlje procured this food ingredient in large quantities. A number of documents from Dubrovnik archives testify that their merchants predominantly traded salt in Polimlje and that region exported livestock, livestock products and leather which they then took to Dubrovnik (Ćuk, 2005).

\section{The Role of Fresh Water in Stockbreeding}

Access to fresh water was one of the key prerequisites of successful animal husbandry (Mišić, 2007). This area abounded in water sources such as rivers, springs and streams making it exceptionally suitable for stockbreeding and breeders always provided their livestock with plenty of water. The main river of the area is the Lim with its dense net of tributaries - the Ljubovidja, Lješnica (Bijelo Polje), Bistrica, the Mileševska river and the Uvac being the biggest among them (Dragović, 2004). 
The Lim Chart (1254 - 1263) mentions mountain Smračnik as a property of St Peter's Monastery in the Lim District and within its boundaries - the Ravna river and its tributary Bistrica. The village of Cerovo's area included a pond and a stream and villages Rastetina i Neđakusi had streams within their boundaries (Mošin et al., 2011). Ponds and streams served as watering places for the livestock. Water holes in karst areas were of special importance as running water was scarce.

\section{Vlachs - Professional Stockbreeders and their Katuns}

In the first half of XV Century, the number of Vlach communities increased and that enhanced animal husbandry in the region. Professional stockbreeders - known as Vlachs - kept numerous livestock. Vlachs were stockbreeding population of a special status and with a particular organisation. The sheep kept by the Vlachs had black or white wool of lesser quality. Their cheese production, however, was noteworthy since the product was of good quality and in demand on the markets of the coastal towns (Dubrovnik and Kotor) (Babić, 1987). In addition to stockbreeding, transport of merchandise was the key activity of the Vlachs. Together with captains from Dubrovnik, Vlachs brought various commodities on their horses to places in Polimlje, had a rest there and after exchanging goods, returned to Dubrovnik bearing different merchandise (Dinić, 1937).

The first and the oldest Ottoman Census of Herzegovina as a separate administrative division started in 1475 and was completed on 7 - 16 December 1477 (Individual Enumeration of the Sanjak Vilayet Herzegovina - the original title: Derter-i esami sancak-i vilayet Hersek). Roughly speaking, the population of Herzegovina fell into two groups - Vlach stockbreeders and common farmers (rayah). Vlach districts (nahiyas) of Sanjak Herzegovina were a part of the imperial property (Hass). Vlachs had some military obligations to the Ottomans and, in return, had some agricultural taxes concessions and were exempted from the rayah status. According to the Individual Enumeration of the Sanjak Vilayet Herzegovina of 1475/77, this administrative division comprised Vlach (stockbreeding) nahiyas. The census informs us about the number of katuns in each district, where the stockbreeders and their animals wintered and where their best summer grasslands were (Aličić, 1985). This seasonal transhumance was also terrain induced. Apart from meaning "shepherds' summer hut in the mountain" the term katun in the Middle Ages also denoted Vlach's local social organisation based on their lifestyle. Katuns were headed by the leaders called katunar and knez. The katunar was the head of a katun responsible for the vital role of the Vlach stockbreeding production. The knez was the political head of the local self-government who represented the Vlachs, determined winter and summer accommodations and regulated interrelations in the katun (Hrabak, 1997).

Vlach stockbreeding communities were listed in the following nahiyas: Mataruge, Kukanj, Mileševa and Ljubovidja. In this area, winter accommodations were in Drenova, Bistrica, Izbično, Dolne Prnar, Varine, Lješnica, Hranac, Ljubovidja and some other places. Summer pastures were in the mountains Ljubišna, Jadovik, Pobjenik, Zlatar, Babina, Hranča, Krnja jela, Kričani, Boranje, Barica, etc. Seasonal movements of the Vlachs from winter to summer accommodations had been a tradition for several centuries in this part of the Balkans, and katun was the primary social unit of a stockbreeding society in the Middle Ages. The Census enumerated 38 katuns, 911 households and 169 single adult members in these Vlach nahiyas. 4704 Vlachs lived there (Aličić, 1985). In addition to this stockbreeding community, the mountains accommodated some members of the gentry, as well. Ivaniš Pavlović stayed on the Bujak mountain in Septemer 1442 and from there confirmed the privileges that Dubrovnik had been granted. Mountain Bujak is situated on the right bank of the Lim near its confluence with the Drina (Dinić, 1978, 256).

\section{Sheep Raising in the Ottoman Defter of $\mathbf{1 5 8 5}$}

The tax on the small livestock was paid exclusively to the state and the livestock population was noted in a special defter (tax register $-\mathrm{T}$. N.) which was then used for collecting the state revenue. These regulations contained the detailed information which included: names of the settlements, livestock owners and the number of animals. A tax was collected for sheep and goats excluding lambs and kids less than a year old. During the reign of the Sultan Mehmed II (1451 1481) an akçe was taken for every three sheep, and towards the end of his rule - for every two sheep. This amount remained unchanged almost until the end of XVI Century. Such small taxation was a good incentive for the development of animal husbandry. In addition to the sheep tax, a sheepfold tax was also collected and in XV Century and the first half of XVI Century it was three akçe per flock. Later it was raised to five akçe. Both taxes were collected at the beginning of April every year (Hadžibegić, 1969). The mountainous area of Polimlje with its vast and rich pastures was ideal for sheep raising. Regarding the pastures, the best region was Peštersko-sjenička plateau (Lutovac, 1977). The sheep and sheepfold tax defter for kaza Bihor of 1585 gives evidence that sheep raising was a major economic activity. A certain 
number of villages in kaza Bihor belonged to Middle Polimlje. The Census recorded that the majority of stockbreeders were Orthodox Christians (Hadžibegić, 1969). The number of animals enumerated in the Census was substantial and this further proves our notion that sheep raising was the chief economic activity of the region in the Middle Ages.

\section{Horses and Pigs}

The degree to which animal husbandry was developed can also be measured by the oats tax. Oats was mainly used as horse food and that is why it was sowed. Similar to Medieval Bosnia and Serbia, special attention was paid to horse breeding. A small, sturdy, mountain horse which did not require much food and could endure hard labour was most frequently bred. Horses grazed near the settlement and in the evening they were brought into the stables and given oats for further feeding (Kurtović, 2014). The 1475/77 Ottoman defter contained records of tithe on oats being paid in almost every settlement which implied a considerable number of horses there (Aličić, 1985). Horses were very important as load carrying animals and had a significant role in the caravan trade. They were the only means of transportation in Polimlje (Miljković, 2010).

Pig farming was also developed in this area. Pigs did not have big needs in terms of maintenance and were taken out for feeding to the nearby rough grazing and groves where they fed on various plants and oak and beech acorns (Mrgić, 2013). Two sorts of pigs were raised - black and white (Hrabak, 1995). Besides being locally consumed, they were a trading commodity since their number exceeded domestic needs. Pigs were sold in Dubrovnik and in the town squares elsewhere (Kovačević-Kojić, 1987). The information collected from the individual enumeration conclusively prove that pig raising continued throughout the Ottoman rule. In this area, pig tax was collected in 152 villages (Aličić, 1985). Although Muslim Faith prohibits pig raising and pork consumption, the Christians were allowed to keep pigs and consume their products.

\section{Conclusion}

The territory of Lower and Middle Polimlje was very suitable for the development of animal husbandry because of the numerous high and vast mountains, pastures, forests, rivers, streams and springs. In the Middle Ages, livestock keeping was of multiple importance for the population since its products provided everyday food and milk, cheese, kaymak, butter and meat were irreplaceable parts of the local diet. Other products, such as wool, fleece and leather were used for clothing. Principal livestock was sheep, followed by cattle and goats. Due to its profitability, animal husbandry was practiced not only in mountainous regions but in arable valleys as well. Additionally, stockbreeding products were important trading commodities - the fact that also had a favourable effect on the development of animal husbandry. Among livestock products, skin was an important export item as well as meat and cheese which were taken to Dubrovnik both by local people of Polimlje and by Dubrovnik merchants. In the Middle Ages, Dubrovnik was a stable market for Polimlje livestock products.

A number of records on pastoral tithe give evidence that villages had their own grassland. In addition to village pastures, the area had the district grassland as well. While animals grazed in summer, they were mainly fed on dry forage in winter. Professional stockbreeders - known as the Vlachs - kept large transhumance flocks and herds that moved between fixed summer and winter pastures. In these parts, a katun was the basic unit of the stockbreeding society. These communities were enumerated in the 1475/77 defter in the following nahiyas: Mataruge, Kukanj, Mileševa and Ljubovidja. They had fixed winter and summer pastures in Middle Polimlje. Pig farming was extensive and lasted throughout the Ottoman rule as recorded in the 1475/77 Census.

\section{References}

Aličić, A. S. (1985). Poimenični popis sandžaka vilajeta Hercegovina [The detailed register of the Sandjak of Herzegovina vilaya]. Sarajevo: Orijentalni institut.

Babić, A. (1987). Društvo srednjovjekovne bosanske države [Society of the mediaeval Bosnia]. In E. Redžić (Eds.), Prilozi za istoriju Bosne i Hercegovine I. Društvo i privreda srednjovjekovne bosanske države (pp. 21-83). Sarajevo: Akademija nauka i umjetnosti Bosne i Hercegovine.

Blagojević, M. (1966). Planine i pašnjaci u srednjovekovnoj Srbiji (XIII i XIV vek) [Mountains and pastures in medieval Serbia (thirteenth and fourteenth century)]. Istorijski glasnik, 2-3, 3-95.

Blagojević, M. (2007). Zemljoradnički zakon: srednjovekovni rukopis [Agricultural law: medieval manuscript]. Beograd: Srpska akademija nauka i umetnosti.

Čelebija, E. (1957). Putopis: odlomci o jugoslavenskim zemljama II [A travelogue: Excerpts of Yugoslav countries II]. (H. Šabanović, 
trans.). Sarajevo: Svjetlost.

Ćuk, R. (2005). Polimlje u srednjem veku: ljudi i poslovi [The Polimlje region in the Middle Ages: merchants and transactions]. Mileševski zapisi, 6, 23-33.

Dinić, M. (1937). Dubrovačka srednjovekovna karavanska trgovina [Dubrovnik's medieval caravan trade]. Jugoslovenski istoriski časopis, 1-4, 119-145.

Dinić, M. (1978). Srpske zemlje u srednjem veku [Serbian country in the Middle Ages]. Beograd: Srpska književna zadruga.

Dragović, R (2004). Polimlje: priroda, turizam, održivi razvoj [Polimlje: nature, tourism, sustainable development]. Beograd: Srpsko geografsko društvo.

Hadžibegić, H. (1969). Zvanični podaci o stočnom fondu na područiju Novog Pazara, Trgovišta i Bihora iz 1585. godine [Official data on livestock in the area of Novi Pazar, Trgoviste and Bihor in 1585.]. Istorijski zapisi, XXVI/4, 585-616.

Hrabak, B. (1969). Putnici iz hrišćanske Evrope o privrednim prilikama slovenskih zemalja na Balkanu pod Turcima u XVI veku [Travelers from the Christian Europe on economic situation of the Slavic countries in the Balkans under the Ottomans in the sixteenth century]. Zbornik Filozofskog fakulteta u Prištini, VI, 1-43.

Hrabak, B. (1995). Poljoprivreda Bosne i Hercegovine 1463-1700. godine [Agriculture in Bosnia-Herzegovina in the period 1463-1700]. In S. Terzić (Eds.), Bosna i Hercegovina od srednjeg veka do novijeg vremena (pp. 183-200). Beograd: Istorijski institut.

Hrabak, B. (1997). Čelnici stočarskih zajednica u istočnoj Hercegovini u XIII- XIV veku [Chiefs of cattle raising communities eastern Hercegovina in XIII-XIV century]. Zbornik za istoriju Bosne i Hercegovine, 2, 139-159.

Katić, R. (1978). Stočarstvo srednjovekovne Srbije [Animal Husbandry in medieval Serbia]. Beograd: Srpska akademija nauka i umetnosti.

Kovačević-Kojić, D. (1987). Privredni razvoj srednjovjekovne bosanske države [The economic development in medieval Bosnian state]. In E. Redžić (Eds.), Prilozi za istoriju Bosne i Hercegovine I. Društvo i privreda srednjovjekovne bosanske države (pp. 85-190). Sarajevo: Akademija nauka i umjetnosti Bosne i Hercegovine.

Kurtović, E. (2014). Konj u srednjovjekovnoj Bosni [Horses in medieval Bosnia]. Sarajevo: Univerzitet.

Lutovac, M. (1933). Stočarstvo na severoistočnim Prokletijama [Animal husbandry in northeastern Cursed Mountains]. Beograd: Geografsko društvo.

Lutovac, M. (1977). Stočarstvo i stočarski život na Peštersko - sjeničkoj visoravni [Cattle breeding and the life of cattle breeders in the Pester-Sjenica plateau]. Zbornik radova Geografskog instituta "Jovan Cvijić", 29, 157-170.

Miljković, E. (2010). Krstareći osmanskim carstvom: putevi i gradovi [Throughout the Ottoman Empire: roads and towns]. Teme, 1, 348350.

Mišić, S. (1996). Humska zemlja u srednjem veku [The Land of Hum in the Middle Ages]. Beograd: DBR International Publishing.

Mišić, S. (2007). Korišćenje unutrašnjih voda u srpskim zemljama srednjeg veka [Using of internal water in the medieval Serbian lands]. Beograd: Utopija.

Mošin, V., Cirković, S., \& Sindik, D. (2011). Zbornik srednjovekovnih ćirilskih povelja i pisama Srbije, Bosne i Dubrovnika, knj. I 11861321 [The collection of medieval charters and Cyrillic letters from Serbia, Bosnia and Dubrovnik, Vol. I 1186-1321]. Beograd: Istorijski institut.

Mrgić, J. (2013). Zemlja i ljudi: iz istorije životne sredine Zapadnog Balkana [Land and People: from the Environmental History of the Western Balkans]. Beograd: Equilibrium. 